\title{
SEDIMENT ORGANIZATION AND ADJUSTMENT IN A TORRENTIAL REACH OF THE UPPER IJUEZ RIVER, CENTRAL SPANISH PYRENEES
}

\author{
A. GÓMEZ-VILLAR ${ }^{1 *}$, Y.SANJUÁN², J.M. GARCÍA-RUIZ², \\ E. NADAL-ROMERO ${ }^{3}$, J. ÁLVAREZ-MARTÍNEZ ${ }^{4}$, \\ J. ARNÁEZ ${ }^{5}$, M.P. SERRANO MUELA ${ }^{2}$ \\ 'Departamento de Geografía y Geología, Universidad de León, \\ Campus de Vegazana, 26071 León, Spain. \\ 2Instituto Pirenaico de Ecología, CSIC, \\ Campus de Aula Dei, Apartado 13034, 50080 Zaragoza, Spain. \\ ${ }^{3}$ Departamento de Geografía y Ordenación del Territorio, \\ Universidad de Zaragoza, 50009 Zaragoza, Spain. \\ ${ }^{4}$ Departamento de Ingeniería Agrícola y Forestal, \\ Universidad de Valladolid, Campus La Yutera, 34071 Palencia, Spain. \\ ${ }^{5}$ Área de Geografía Física, Universidad de La Rioja, 26004 Logroño, Spain.
}

\begin{abstract}
The dynamics of the torrential upper reach of the Ijuez River, Central Spanish Pyrenees, was analyzed in relation to the spatial organization of grain size. The reach is located in the Eocene flysch, which usually acts as a high sediment production area, particularly during periods of intense human activity. The Ijuez Valley was cultivated and densely populated until the middle of the 20th century, resulting in general deforestation and the development of debris flows, shallow landslides, sheet wash erosion and deep gullies. As a consequence, the alluvial plain became characterized by the presence of large quantities of coarse sediment. The spatial organization of sediment showed a progressive downstream decline in the cobble and boulder size, especially in the channel, whereas the remainder of the alluvial plain showed large variability. No trend in the occurrence of the largest boulders was evident throughout the reach, confirming the importance of debris and hyperconcentrated flows in sediment transport. The torrential reach did not have a negative exponential longitudinal profile, in contrast to that usually observed for mountain rivers. This was attributed to the large quantity of heterometric sediment derived from the hillslopes, which resulted in no marked decline in sediment size and consequent change in the longitudinal profile. A recent trend of scouring was detected, reflecting the reduction in sediment supply following farmland abandonment and reforestation, which have reduced connectivity between the hillslopes and the channel.
\end{abstract}




\section{Organización y ajuste de sedimentos en un tramo torrencial de la cabecera del río Ijuez, Pirineo central español}

RESUMEN. Se estudia un tramo torrencial en la cabecera del río Ijuez, Pirineo central español, con el fin de analizar su dinámica en relación con la distribución espacial de los sedimentos. Este tramo se instala en el flysch eoceno, que habitualmente se comporta como altamente productor de sedimento, especialmente en condiciones de intensa actividad humana. El valle del río Ijuez fue cultivado y densamente poblado hasta mediados del siglo XX, causando la eliminación de la mayoría de los bosques y dando lugar a flujos de derrubios (debris flows), deslizamientos superficiales, erosión difusa y formación de barrancos muy activos. La consecuencia fue el desarrollo de una llanura aluvial caracterizada por el escombrado de grandes volúmenes de sedimento grueso. La organización espacial de los sedimentos muestra un progresivo descenso en el tamaño de los cantos, especialmente en el cauce actual, y mucho menos en el resto de la llanura aluvial, donde la variabilidad es muy grande. Los grandes bloques no presentan ninguna tendencia a lo largo del curso, reflejando la importancia de los flujos de derrubios e hiperconcentrados en el transporte de sedimento. El tramo torrencial estudiado no muestra un perfil longitudinal exponencial negativo, al contrario de lo que es habitual en los ríos de montaña. Este fenómeno se atribuye a la gran cantidad de sedimentos heterométricos que llegan masivamente desde las laderas, que impiden un marcado descenso en el tamaño del sedimento y el consiguiente ajuste del perfil longitudinal. Se ha detectado una tendencia reciente hacia la incisión del río en sus propios sedimentos, reflejando la reducción en el aporte de estos últimos debido al abandono de tierras y la reforestación, limitando la conectividad entre laderas y cauce.

Key words: torrential reach, debris flows, braided river, channel adjustment, grain size distribution, Central Pyrenees.

Palabras clave: río torrencial, flujos de derrubios, río trenzado, ajustes del cauce, tamaño del sedimento, Pirineo central.

Received 9 January 2014

Accepted 24 January 2014

*Correspondencia: Departamento de Geografía y Geología, Universidad de León, Campus de Vegazana, 26071-León, Spain. E-mail: agomv@unileon.es

\section{Introduction}

Mountain rivers are typically characterized by steep longitudinal gradients, relatively narrow valleys and large variability in the grain-size range. The latter is commonly dominated by coarse fractions (gravels and boulders) (Gómez, 1987), which indicates high-energy environments and the relatively easy access of sediment from hillslopes to channels (Leopold, 1994). Such rivers show extremely large spatial 
variability in sedimentary features and rapid responses to upstream changes, including the construction of check-dams and land cover changes (Brooks and Brierley, 1997; Kondolf et al., 2002; Marston et al., 2003; Liébault et al., 2005; Boix-Fayos et al., 2007; Keesstra, 2007; García-Ruiz and Lana-Renault, 2011; Segura-Beltrán and Sanchis-Ibor, 2013). Torrential rivers, or torrents, are particular types of mountain rivers, with longitudinal gradients $>5 \%$, unstable geological formations, and sediment dominated by boulders and blocks that enter the streambed mainly through debris flows and landslides (Rickenmann, 1997; Benda et al., 2005; D'Agostino, 2013; Picco et al., 2014). Torrents are generally short, and can be affected by large variability in discharge and the occurrence of sudden floods with very destructive capacity (White et al., 1997). This can involve changes in flow from zero to hundreds of cubic metres per second in a very short period of time, resulting in rearrangement of the riverbed morphology (D'Agostino, 2013). Some of such events are associated with high magnitude rainfall and catastrophic floods (Elfström, 1987). Schumm (1977) and Benda et al. (2005) reported that torrential headwater streams behave as sediment reservoirs for long periods, conditioning the sediment transport and streambed morphology many kilometres downstream.

Mountain rivers have frequently been studied to investigate bed morphology and the evolution of sediment characteristics along reaches of different lengths in relation to hydraulic or environmental features. The longitudinal profile of mountain rivers and the downstream variation in bed material size, particularly downstream fining, have been the focus of many studies (e.g. Church and Kellerhals, 1978; Knighton, 1980; Brierley and Hickin, 1985; Seal and Paola, 1995; Dawson, 1988; Ferguson et al., 1996; Hoey and Ferguson, 1997; Montgomery and Buffington, 1997; Powell, 1998; Rice and Church, 1998; Hoey and Bluck, 1999; Rice, 1999; Gomez et al., 2001; Surian, 2002; Gasparini et al., 2004; Moussavi-Harami et al., 2004; Frings, 2008).

Previous studies in the Pyrenees have underlined the torrential character of some fluvial stretches, particularly within the flysch area, as a consequence of structural features (García-Ruiz and Puigdefábregas, 1982; García-Ruiz et al., 1990), and intensive deforestation, grazing and agricultural activities (García-Ruiz and Valero, 1998), which have resulted in shallow landslides that evolve into debris flows and high erosion rates. Some very dramatic geomorphic consequences have been reported in this area, including the large debris flows that buried the San Adrián de Sasave Monastery (Martí et al., 1997) and the recent Biescas campsite disaster, in which the lower reach of a torrent was affected and resulted in 89 casualties (White et al., 1997). Other studies have focused on the dynamics of alluvial fans at the lower end of Pyrenean torrents (Gómez-Villar and García-Ruiz, 2000) and the effects of control works (check-dams) on the evolution of torrential rivers in the flysch area (García-Ruiz and Puigdefábregas, 1985; García-Ruiz et al., 2010).

Among the Pyrenean torrents, the headwater of the Ijuez River reflects major activity, suggesting the occurrence of intense hillslope geomorphic processes and rapid connectivity with the channel. Nevertheless, changes in activity have been reported in relation to changes in land cover in both the middle and high mountain belts. Martínez- 
Castroviejo and García-Ruiz (1990) confirmed exceptional sediment yield from the hillslopes and substantial fluvial adjustments that resulted in sediment transfer to the lower stretches of the river. Beguería (2006) investigated the evolution of debris-flow activity in the Ijuez Valley, and reported a slight annual reduction in the number of debris flows and a change in the conditions triggering them because of shrub and forest expansion. Bathurst et al. (2007) applied the SHETRAN model to assess debris-flow activity in the Ijuez basin and to estimate the contribution of debris flows to the overall catchment sediment yield. Pueyo and Beguería (2007) studied the secondary succession of plant cover following farmland abandonment in the Ijuez catchment, and confirmed the recent expansion of forests. The studies noted above have highlighted: (i) the importance of debris flows and high sediment yield in explaining the dynamics of the headwater of the Ijuez River; and (ii) the spatial organization of sediment along a very active reach. The present study focused on downstream sediment fining in relation to distance and gradient, and differences in the types of sediments (active channel, reorganized debris flows, and old non-reorganized debris flows). The main purpose was to investigate the complexity of the response of a torrential reach affected by the arrival of large quantities of coarse sediment.

\section{Study area}

The Ijuez River is a tributary of the Upper Aragón River, Central Spanish Pyrenees (Fig. 1A). The total area of the basin is $45 \mathrm{~km}^{2}$. Elevation in the basin ranges from 838 to $2173 \mathrm{~m}$ a.s.l. However, the torrential reach selected for this study drains an area of $5 \mathrm{~km}^{2}$ between $1180 \mathrm{~m}$ and $2173 \mathrm{~m}$, with an equilibrated distribution between 1300 and $2100 \mathrm{~m}$ (Fig. 1B and 1C). The bedrock is Eocene flysch with alternating thin beds of sandstone and marl. The flysch is extremely faulted and folded, with recumbent anticlines towards the south. The relief is characterized by the presence of smooth, wide divides that descend progressively towards the south and probably belong to distinct very ancient erosion surfaces. The hillslopes are usually rectilinear and covered by a stony, clastsupported colluvium. The mean gradient of the area is approximately $25-30^{\circ}$, although most of the catchment has a gradient of $25-35^{\circ}$, and a substantial proportion has a gradient $>35^{\circ}$ (Fig. 1D). The steepest gradients are mostly concentrated around the headwater ravines. Deep-seated and shallow landslides occur throughout the basin. The river banks are highly unstable because of lateral channel wandering and undermining.

The climate is sub-Mediterranean, with substantial oceanic influence. The mean annual rainfall $8 \mathrm{~km}$ south at Jaca is $874 \mathrm{~mm}$, and is approximately 2000-2200 mm in the upper divide (García-Ruiz and Puigdefábregas, 1982). Most precipitation falls during the cold period (October-May), and is particularly concentrated in autumn and spring. The mean annual temperature is $9-10^{\circ} \mathrm{C}$ in the lowest sector of the basin $\left(11.4^{\circ} \mathrm{C}\right.$ at Jaca). Snowfalls are frequent between November and April, when a continuous snowpack is usually present above $1650 \mathrm{~m}$. Snowmelt and spring rainfall lead to relatively high discharges in April and May (Lana-Renault et al., 2010), whereas summer flows are very low, with some reaches drying up. Large floods can occur in autumn. 

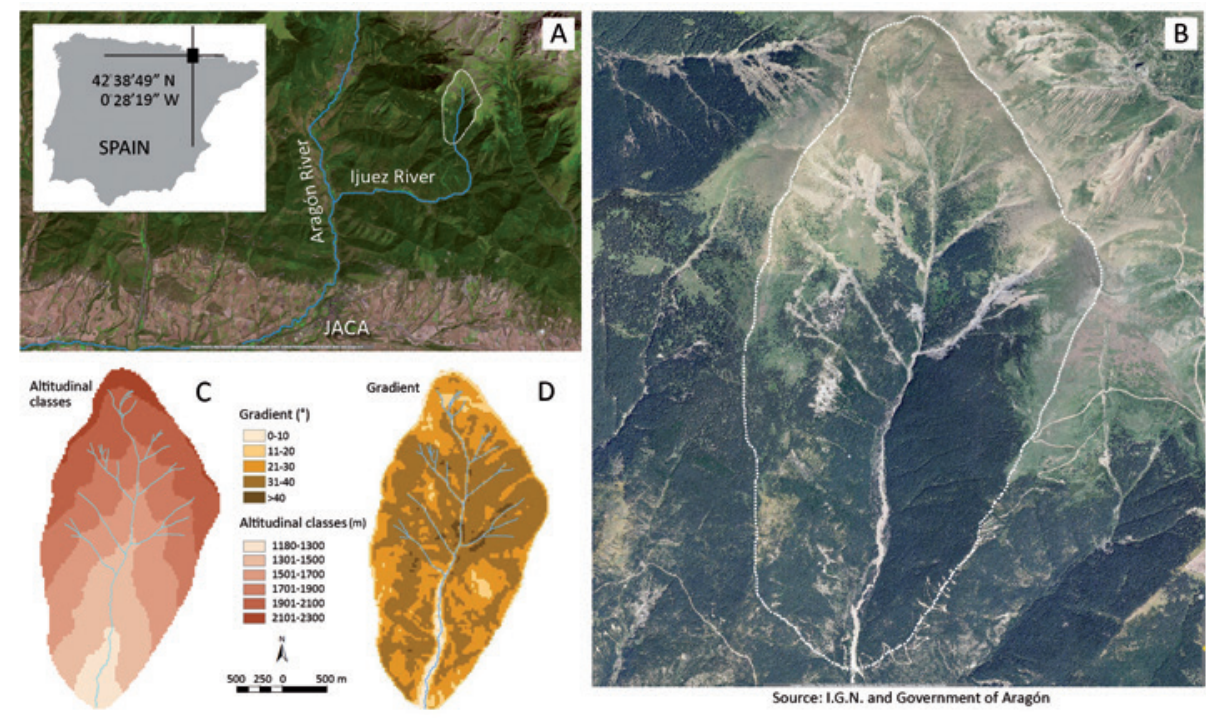

Figure 1. The study area. A: Location of the Ijuez River, tributary of the Aragón River, Central Pyrenees; B: The headwater of the Ijuez basin; C: Altitudinal classes in the Ijuez River headwater; D: Gradient classes in the Ijuez River headwater.

With the exception of the subalpine belt, most of the basin was cultivated on sloping and partially bench-terraced fields, particularly on the south-facing slopes (Vicente-Serrano et al., 2004; Lasanta-Martínez et al., 2005), which caused major erosion. In 1950 the total population was 347, distributed among five villages. In 1957, $60.9 \%$ of the Ijuez Valley was cultivated; the percentage was probably greater at the beginning of the 20th century. Forests represented only $24.7 \%$ of the area (Beguería, 2006). Farmland abandonment occurred from the beginning of the 20th century and accelerated in the $1950 \mathrm{~s}$, resulting in a complex process of plant colonization comprising widespread and dense pine (Pinus sylvestris) forests, and isolated stands of Quercus faginea on the lower south-facing slopes. During the 1950s the basin was purchased by the State Administration and reforested with P. sylvestris and P. nigra to reduce sediment yield and transfer to the Yesa reservoir, which is $65 \mathrm{~km}$ downstream the study area. Consequently, the basin was completely abandoned. Soils on the southfacing slopes are thin, have little organic matter content, and contain a high proportion of stones as a consequence of erosion (Bathurst et al., 2007).

The subalpine belt was also deforested to enlarge the area of summer pastures. This caused extensive erosion, particularly involving shallow landslides (García-Ruiz et al., 2010), which resulted in extreme soil erosion. Declining livestock grazing in the subalpine belt has also contributed to expansion of the upper forest limit, although the presence of eroded thin soils makes rapid recolonization difficult. 
The study reach of the Ijuez River is $2 \mathrm{~km}$ long, between the foot of a waterfall in the headwater and the first of five control structures built in the streambed to retain the bedload. Several tributary ravines flow in steep-sided narrow valleys, directly supplying sediment from valley-confined debris flows.

\section{Methods}

Initially, a survey based on field and aerial images was carried out to identify distinct depositional environments in the most torrential reach of the Upper Ijuez River. This provided an indication of the main stages in the recent evolution of the torrential reach. Land use maps from 1956 and 2009 were produced to identify changes in land cover and their possible effects on fluvial dynamics. A map of gradients in the basin and a longitudinal profile of the studied reach were also developed. Six woody fragments from within the debris flows were dated at the Poznan Radiocarbon Laboratory; these results are not presented here, as the main focus of this study was the active alluvial plain and channels.

The method of Wolman (1954) was used to measure various parameters of the gravels and boulders in the streambed. At selected sampling points, a 25-m tape was placed on the bed, and at each $0.5 \mathrm{~m}$ interval a measurement of the bed material (gravel/boulder) was made to determine its longest axis (a), the shortest axis (b) transverse to the longest axis, and the thickness (c). This process was repeated at each sampling point to provide measurements of up to 100 particles. Data for the (a) or (b) axes were usually used in the statistical analysis.

A total of 55 sampling points were included comprising: (i) 20 in active channels; (ii) 16 in reorganized debris flows in the active alluvial plain; (iii) 15 in old, non-reorganized debris flows; (iv) 4 in the mouth of some tributaries; and (v) 1 in an old fluvial terrace.

The standard sedimentary indices d16, d50 and d84 were used. Based on this information, for each of the sampling points from groups (i), (ii) and (iii), regressions were performed as a function of distance from the headwater $(\mathrm{m})$ and the channel gradient $\left(^{\circ}\right)$. Each distance value was measured from the uppermost part of the basin to the relevant sampling point. The gradient at each point was estimated with a clinometer over a distance of $15 \mathrm{~m}$. The width of the active alluvial plain, which is removed by floods each year, was also measured at each sampling point.

The bed material measurement ratios (a)/(b), (a)/(c), and (b)/(c) were determined for each point, and the values were also related to distance and channel gradient to enable assessment of changes in the ratios among axes and investigation of the relative importance of abrasion to downstream fining. The same analysis was performed using the maximum sizes for (a), (b) and (c) for each sampling point.

The sorting index (Andrews, 1983) was calculated according to the equation:

$$
0.5(\mathrm{~d} 84 / \mathrm{d} 50+\mathrm{d} 50 / \mathrm{d} 16)
$$


The relationship between the channel gradient and the d50/drainage area ratio (Hack, 1957) was calculated, to provide a surrogate measure of the discharge (the drainage area) for explaining the spatial organization of gravel size.

\section{Results}

\subsection{The Ijuez River alluvial plain: a general description and evolutionary stages}

The longitudinal profile showed a very steep gradient $\left(19^{\circ}\right)$ in the uppermost reach of the Ijuez River (Fig. 2), with some steps related to structure (i.e. sandstone outcrops). The stream initially runs in a narrow and incised channel with the presence of few stones. Deep soils affected by shallow landslides are only present in the zeroorder hollow where the Ijuez River channel begins, in an area that is usually dry during the dry season. Along this first reach several very short steep tributaries with active headwaters in the subalpine deforested belt enter the Ijuez River; these apparently supply large quantities of sediment and contribute permanent groundwater discharge. Downstream, the Ijuez River flows over a $60-\mathrm{m}$ waterfall that abruptly reduces the longitudinal gradient to $9^{\circ}$ and progressively to $6-7^{\circ}$. Locally the gradient is approximately $8-10^{\circ}$, mainly in the active channel, resulting in local knickpoints and steps. As Fig. 2 indicates, the longitudinal profile of the Ijuez River develops an almost constant gradient, with only local changes that in most cases can be explained by the presence of trunks and large blocks in the alluvial plain.

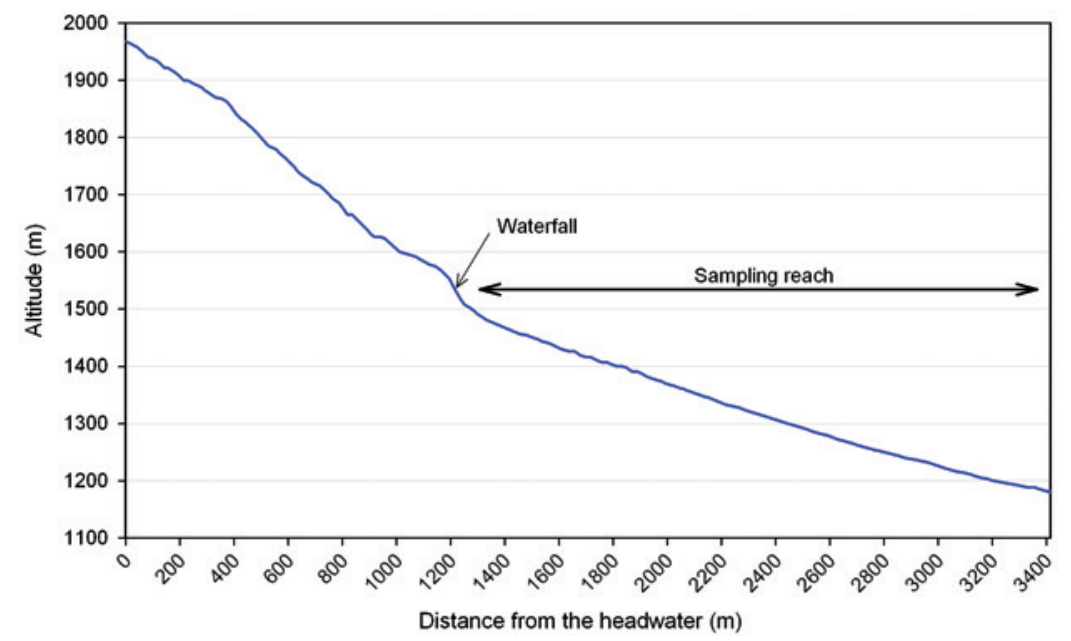

Figure 2. The longitudinal profile of the upper reach of the Ijuez River.

Immediately downstream of the waterfall (at approximately 1300-1400 m from its source), the Ijuez River flows into a deep, narrow canyon (approximately $8 \mathrm{~m}$ width) containing remobilized debris flows in the channel (Fig. 3). Increasing volumes of 
sediment arrive to the channel from the uppermost tributaries and from new, very active ravines. These areas have been partially colonized by forests in the last 40 years, although the headwaters remain deforested and affected by channel incision and severe sheet wash erosion (Fig. 4). Nevertheless, it is noteworthy that some of the tributaries do not show evidence of current activity, with no fresh sediment present up to the junction with the main river. Some have a step of approximately $3 \mathrm{~m}$ at the junction, suggesting that incision in the Ijuez River has been faster that in the tributaries. Downstream of the canyon the valley widens to $80-100 \mathrm{~m}$, which favours sedimentation of coarse particles, and unstable channels wander and change position, forming a braid-like morphology (Fig. 5). A relatively clear distinction is evident between the most active and some secondary channels (approximately $4 \mathrm{~m}$ width), and the remainder of the alluvial plain, which has produced chaotic accumulation of coarse materials. A small fluvial terrace ( $3 \mathrm{~m}$ above the active alluvial plain, and $4 \mathrm{~m}$ in the lowest part of the study reach) is apparent on the right side of the valley bottom. This shows short lateral development (less than $5 \mathrm{~m}$ at the beginning, up to $150 \mathrm{~m}$ in some sites downstream), between the active alluvial plain and the hillslope of the valley. In most places the main terrace appears to have been covered by many debris flows, and is characterized by chaotic deposition of large boulders arranged in a lobed convex form the upper part of which is approximately 2-3 m above the terrace surface (Fig. 6). The channel shows an almost general incision of approximately $1 \mathrm{~m}$ below the alluvial plain.

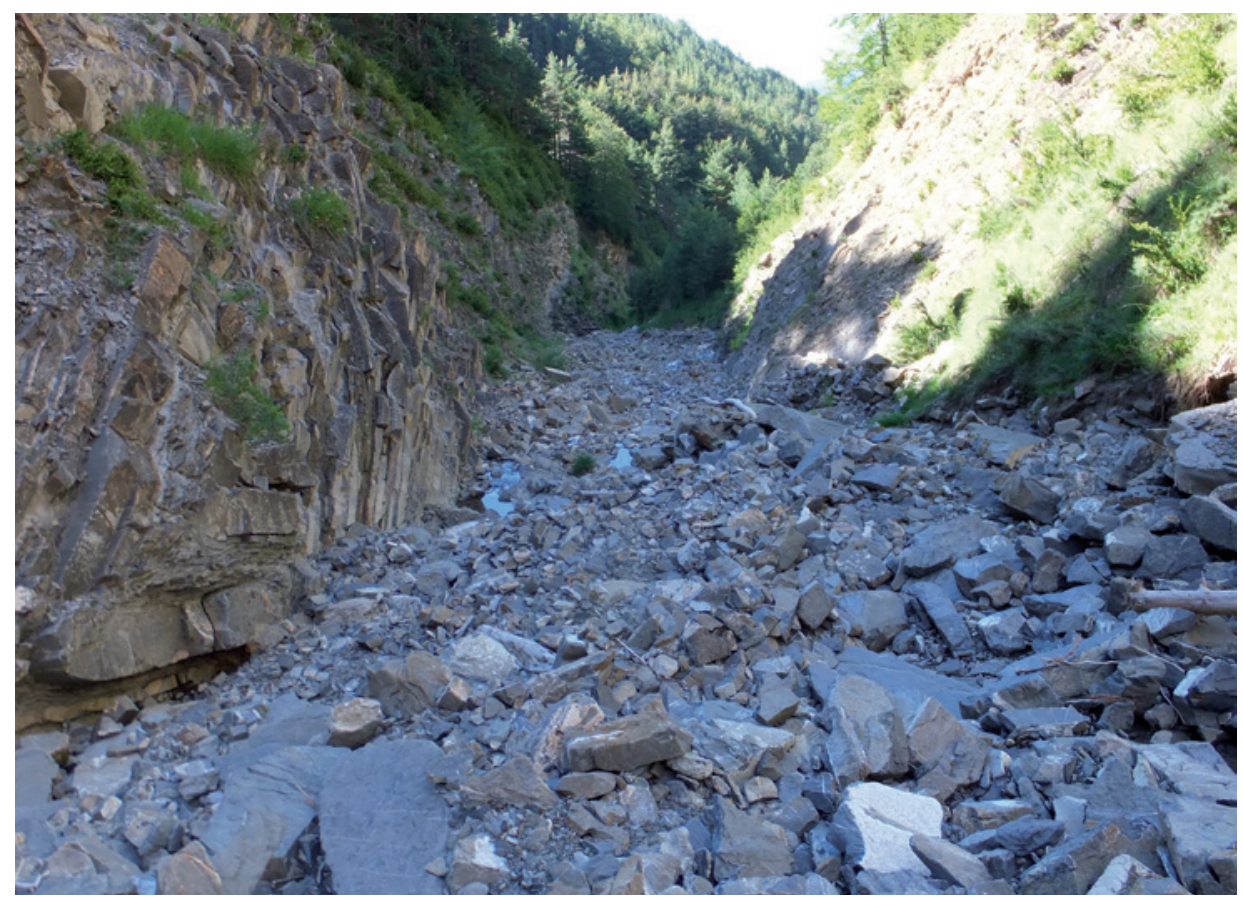

Figure 3. The headwater reach of the Ijuez River, flowing through a canyon. The channel shows chaotic accumulation of blocks composed of flysch sandstone. 


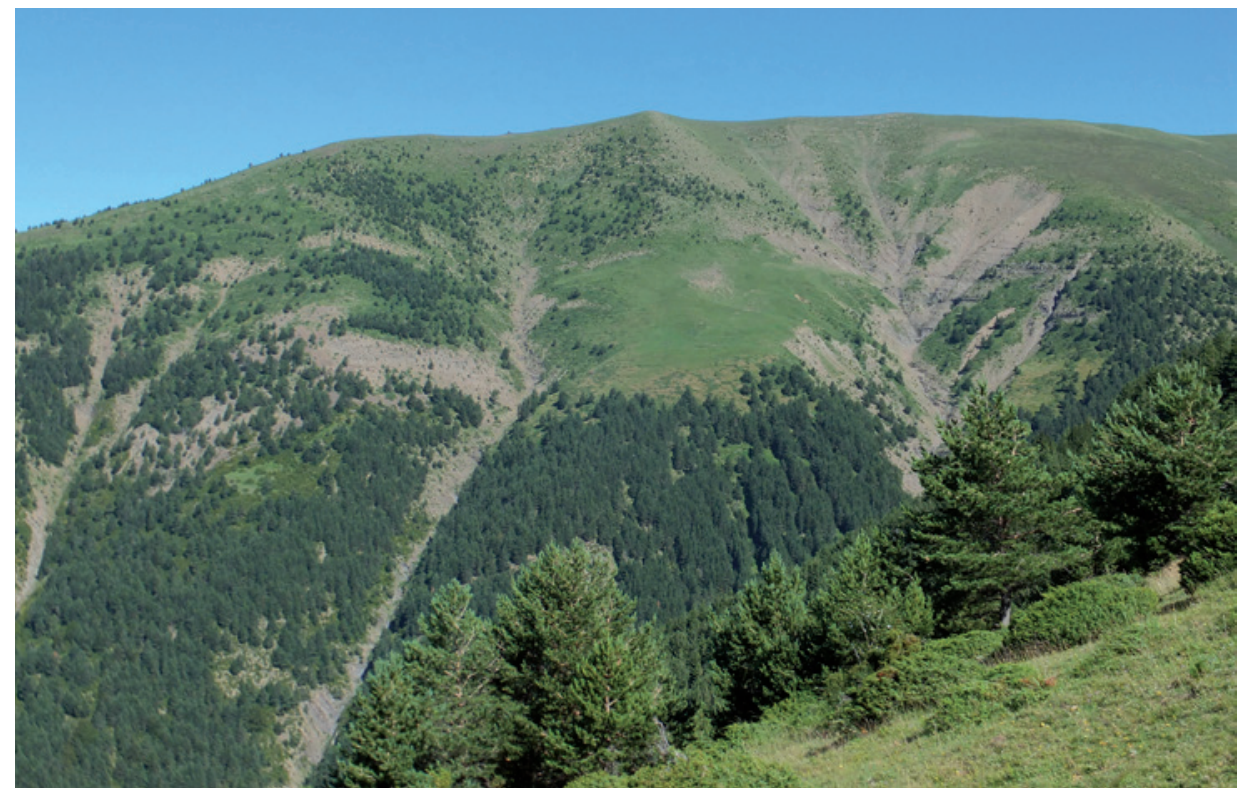

Figure 4. Active headwaters of ravines in the subalpine belt, which supply large volumes of sediment.

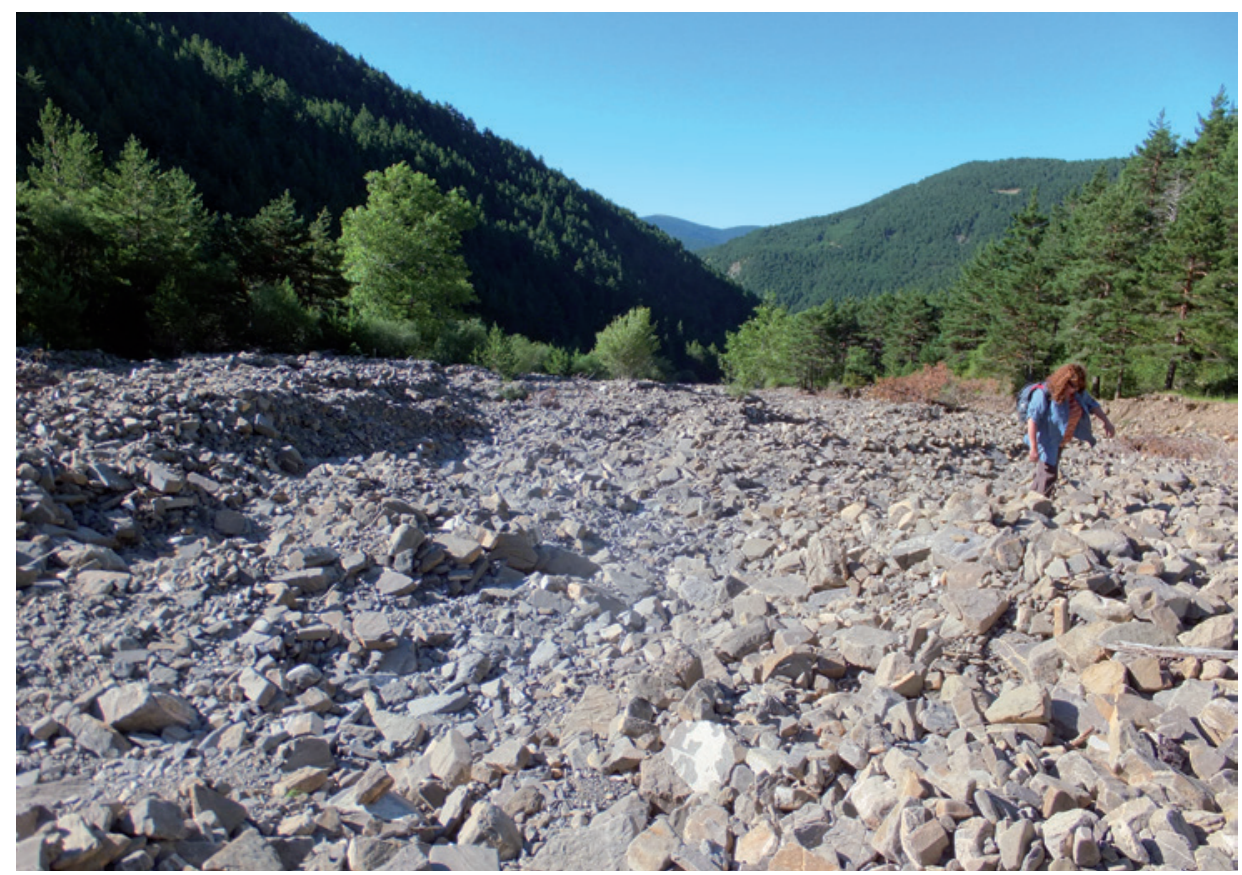

Figure 5. Accumulation of blocks in the Ijuez, River, showing ephemeral channels and a braided morphology. 


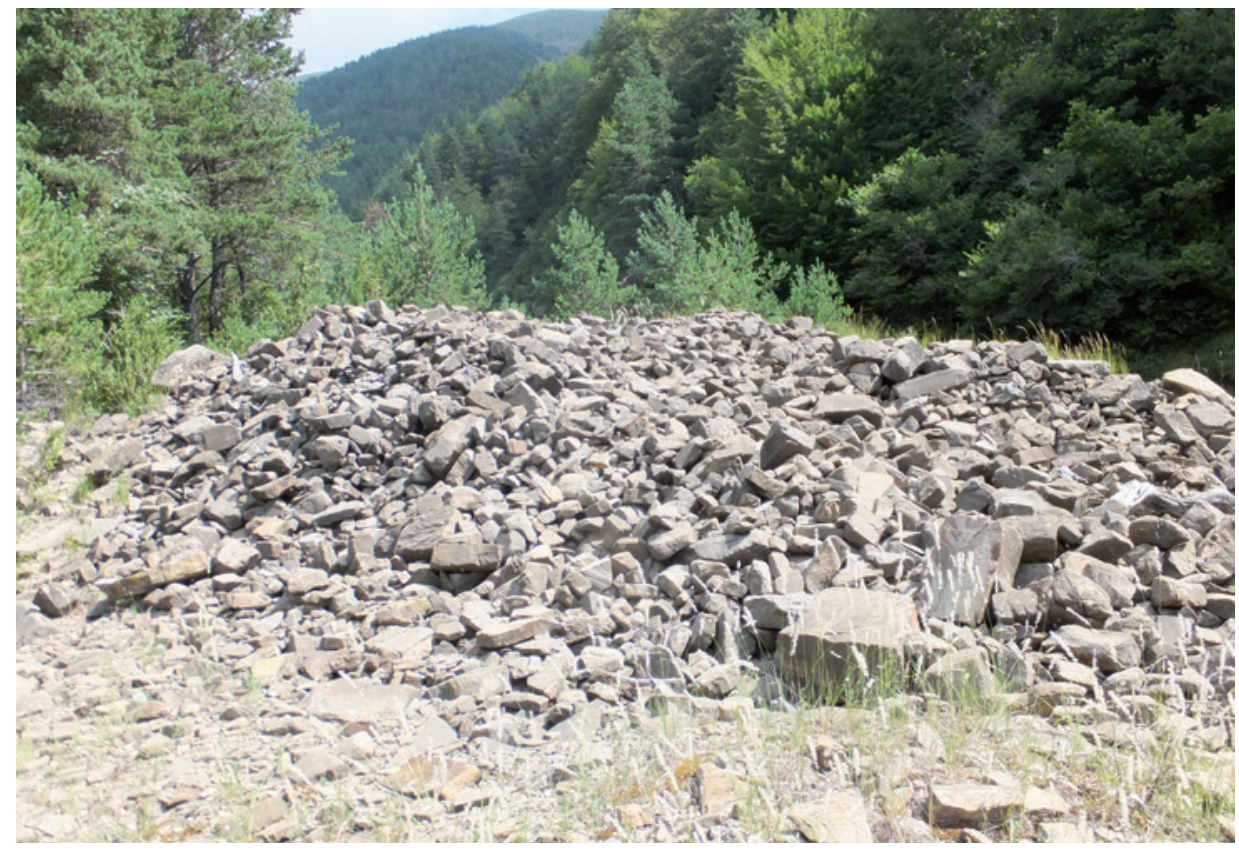

Figure 6. A large debris flow deposit on the fluvial terrace.

\subsection{The spatial organization of sediment in the active alluvial plain}

Fig. 7 shows the frequency distribution of the grain size in the channel, the reorganized debris flows in the active alluvial plain, and the old, non-reorganized debris flows, and distinguishes $\mathrm{d} 16, \mathrm{~d} 50$ and $\mathrm{d} 84$. Coarse grains clearly dominate in the three environments. In the case of d50 there was little gravel $<15 \mathrm{~cm}$, with the predominant classes being $15-30 \mathrm{~cm}$. Some differences were evident among the environments: the greatest concentration in the channel was in the $15-20 \mathrm{~cm}$ class, whereas the reorganized debris flows and the old debris flows had greatest concentrations in the $20-25 \mathrm{~cm}$ class. Cobbles $>30 \mathrm{~cm}$ were relatively common in the three environments. In the case of $\mathrm{d} 84$ the grain size distribution was bi-modal in the three environments, with an almost complete coincidence between the channel and the old debris flows. Blocks $>40 \mathrm{~cm}$ were very common, particularly in the channel. Surprisingly, in the case of $\mathrm{d} 16$, the smallest classes $(<15 \mathrm{~cm})$ dominated in the channel and the reorganized debris flows, whereas in the old debris flows classes between 10 and $20 \mathrm{~cm}$ dominated. The accumulated frequencies (Fig. 8) corroborated most of the above results, and also showed differences among the environments. For instance, the analysis of d16 showed a major contrast between the channel and the old debris flows, with the former having high concentrations in the smaller classes, and the latter having high concentrations in the coarser classes. The same was observed in the case of $\mathrm{d} 50$, whereas in $\mathrm{d} 84$ the old debris flows had a relatively high proportion of the smaller blocks. 

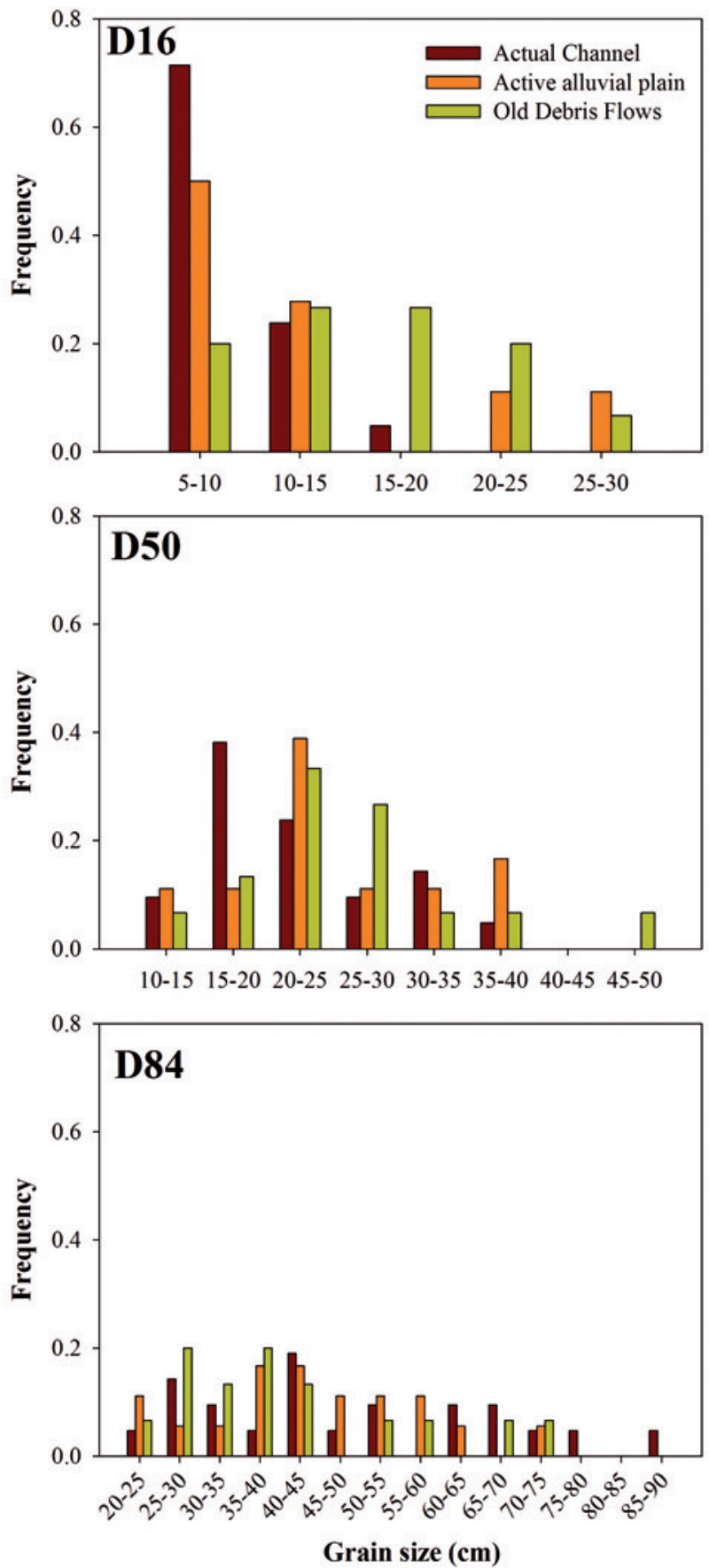

Figure 7. Grain size distribution of d16, 250 and d84 in the active channel, the active alluvial plain and the old debris flows. 

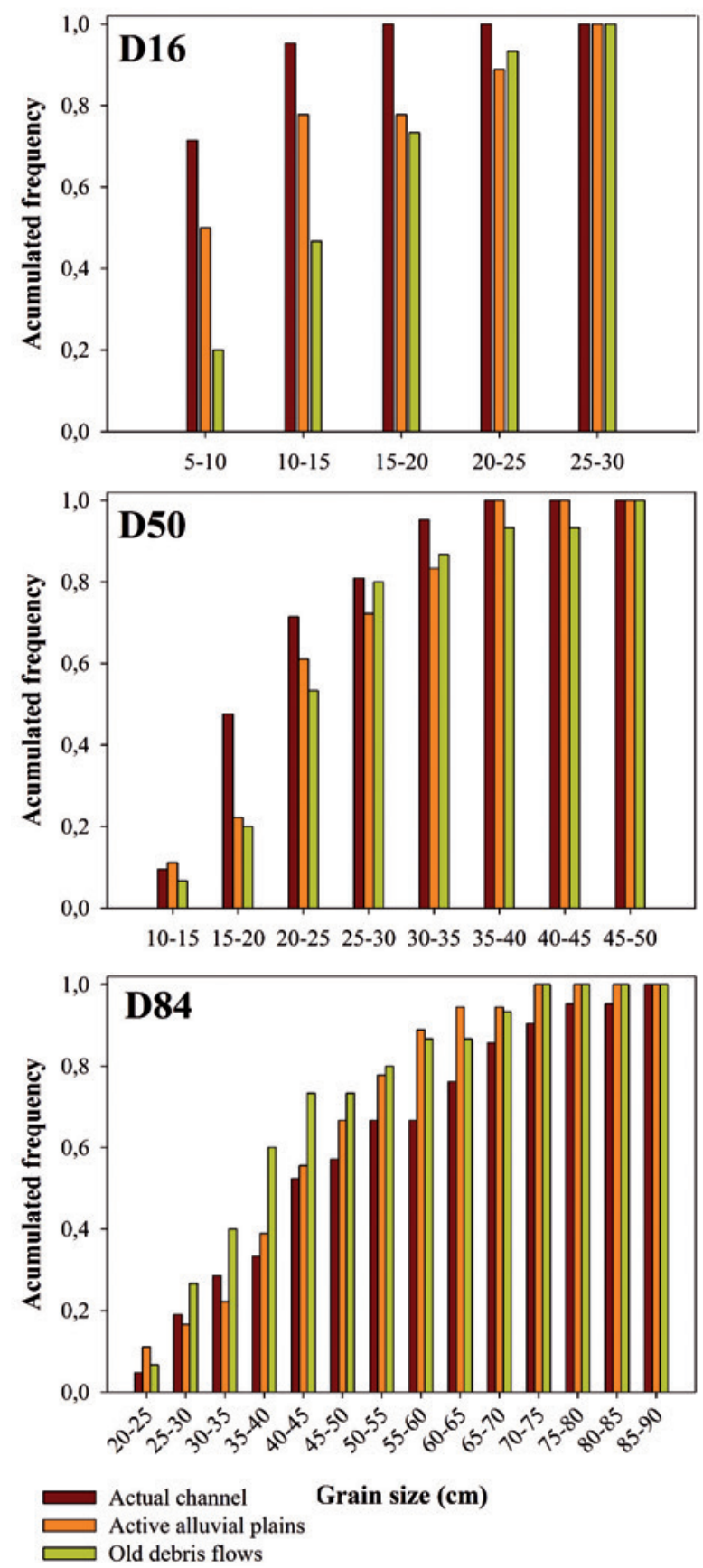

Figure 8. Accumulated frequencies for the grain size distribution of d16, d50 and d84, distinguishing among the channel, the active alluvial plain and the old debris flows. 
The organization of the grain size distribution in relation to distance and gradient is shown for the channel in Fig. 9, for the active alluvial plain in Fig. 10, and for the old debris flows in Fig. 11. There was a clear and statistically significant decrease in grain size along the channel in the study reach, for d16, d50 and d84 (Fig. 9), indicating the effects of both sorting and abrasion. For the (a) axis, d50 was approximately $35 \mathrm{~cm}$ at the most upstream sites, and approximately $15 \mathrm{~cm}$ at the most downstream sampling points. In the case of $\mathrm{d} 85$ the reduction in size was more pronounced, from $60-80 \mathrm{~cm}$ to $20-30 \mathrm{~cm}$. The best coefficient of determination was found for $\mathrm{d} 50\left(\mathrm{r}^{2}=0.705 ; \mathrm{p}=0.000\right)$, confirming that this measure best represented each sampling point. The lowest coefficient of determination was for $\mathrm{d} 16\left(\mathrm{r}^{2}=\right.$ $0.366 ; \mathrm{p}=0.006)$. There were also significant relationships between grain size and channel gradient, particularly for $\mathrm{d} 50\left(\mathrm{r}^{2}=0.642 ; \mathrm{p}=0.000\right)$, showing that there was an increase in grain size with increasing gradient. In this case, the greatest scattering was found for $\mathrm{d} 84$, which had a relatively low coefficient of determination $\left(r^{2}=0.341 ; p=0.009\right)$.

\section{ACTUAL CHANNEL}
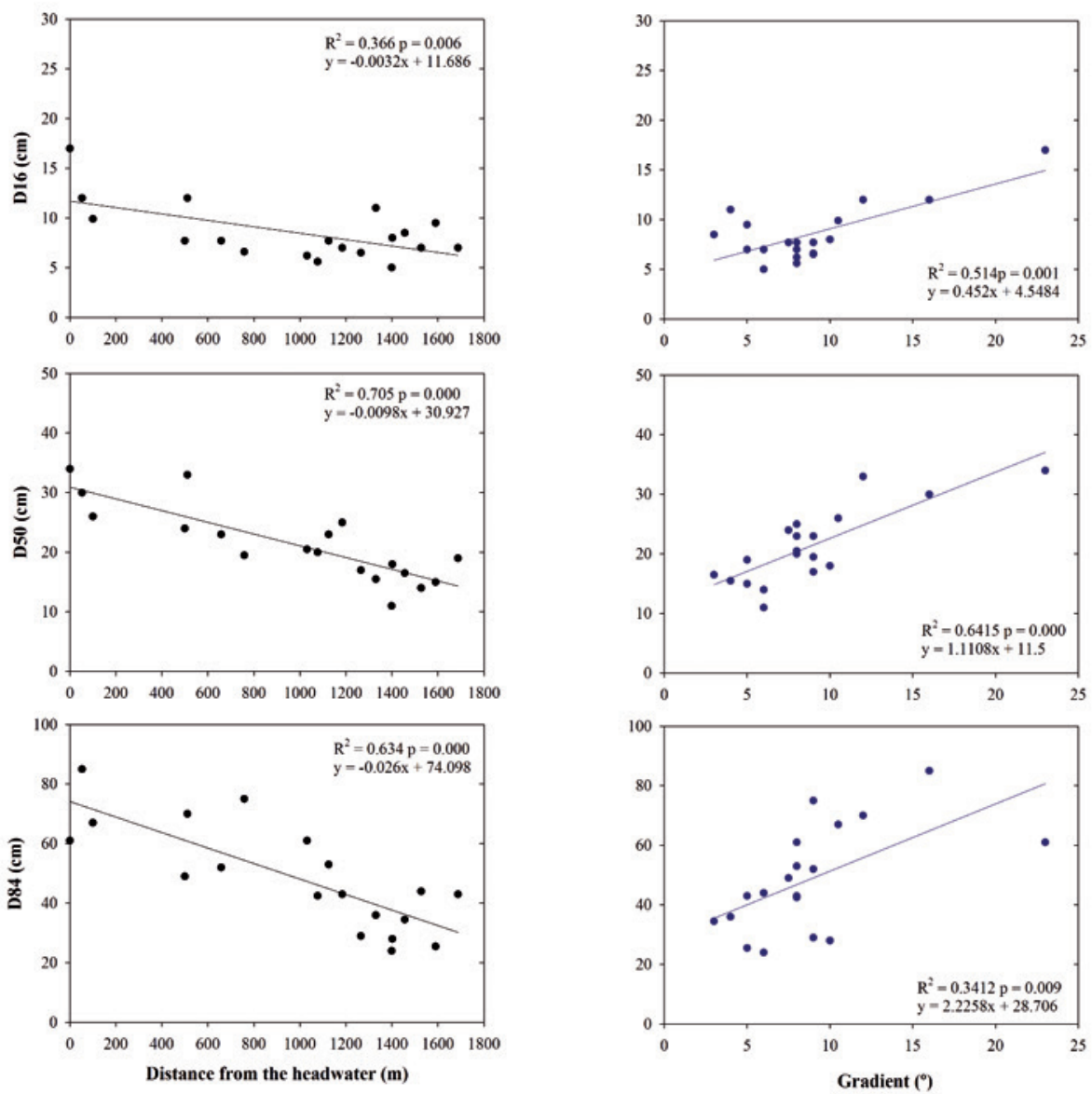

Figure 9. Grain size distribution as a function of distance and gradient in the active channel. 
ACTIVE ALLUVIAL PLAIN
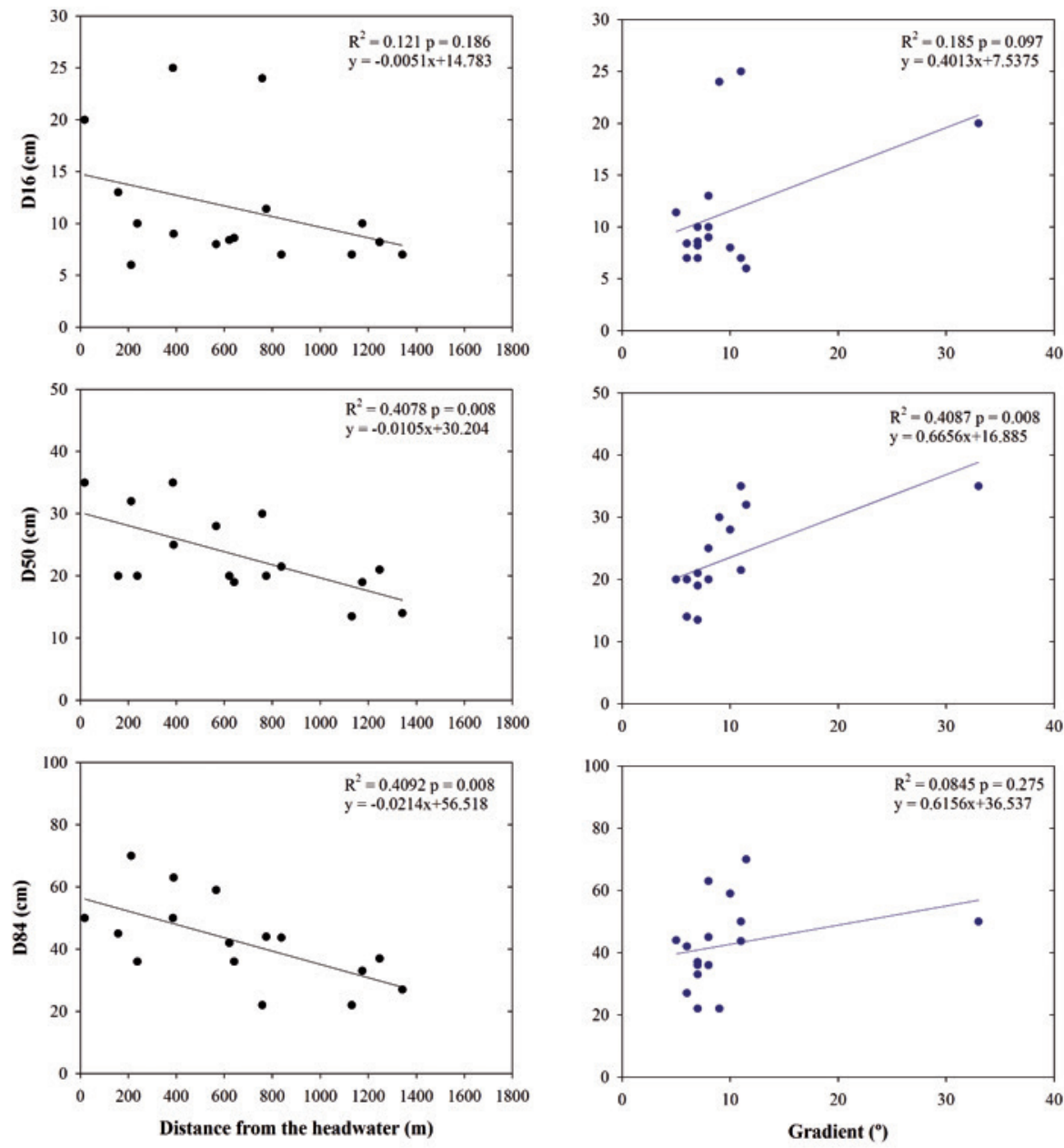

Figure 10. Grain size distribution as a function of distance and gradient in the alluvial plain.

For the alluvial plain, with reorganized debris flows, the relationships between grain size and distance were statistically significant for $\mathrm{d} 50\left(\mathrm{r}^{2}=0.408 ; \mathrm{p}=0.008\right)$ and $\mathrm{d} 84\left(\mathrm{r}^{2}=0.409 ; \mathrm{p}=0.008\right)$, but not for $\mathrm{d} 16$ (Fig. 10). The relationships between grain size and gradient are only statistically significant for $\mathrm{d} 50\left(\mathrm{r}^{2}=0.409 ; \mathrm{p}=0.008\right)$.

For the old debris flows the grain size distribution did not show any relationship to distance or gradient for any of the sizes analysed (d16, d50 and d84), with the distribution of points around the regression lines being chaotic (Fig. 11). To explain the wide dispersion of points, new regressions were performed using the residuals from the relationships between grain size distribution and distance, with gradient as the predictor, but no significant relationships were found. 


\section{OLD DEBRIS FLOWS}
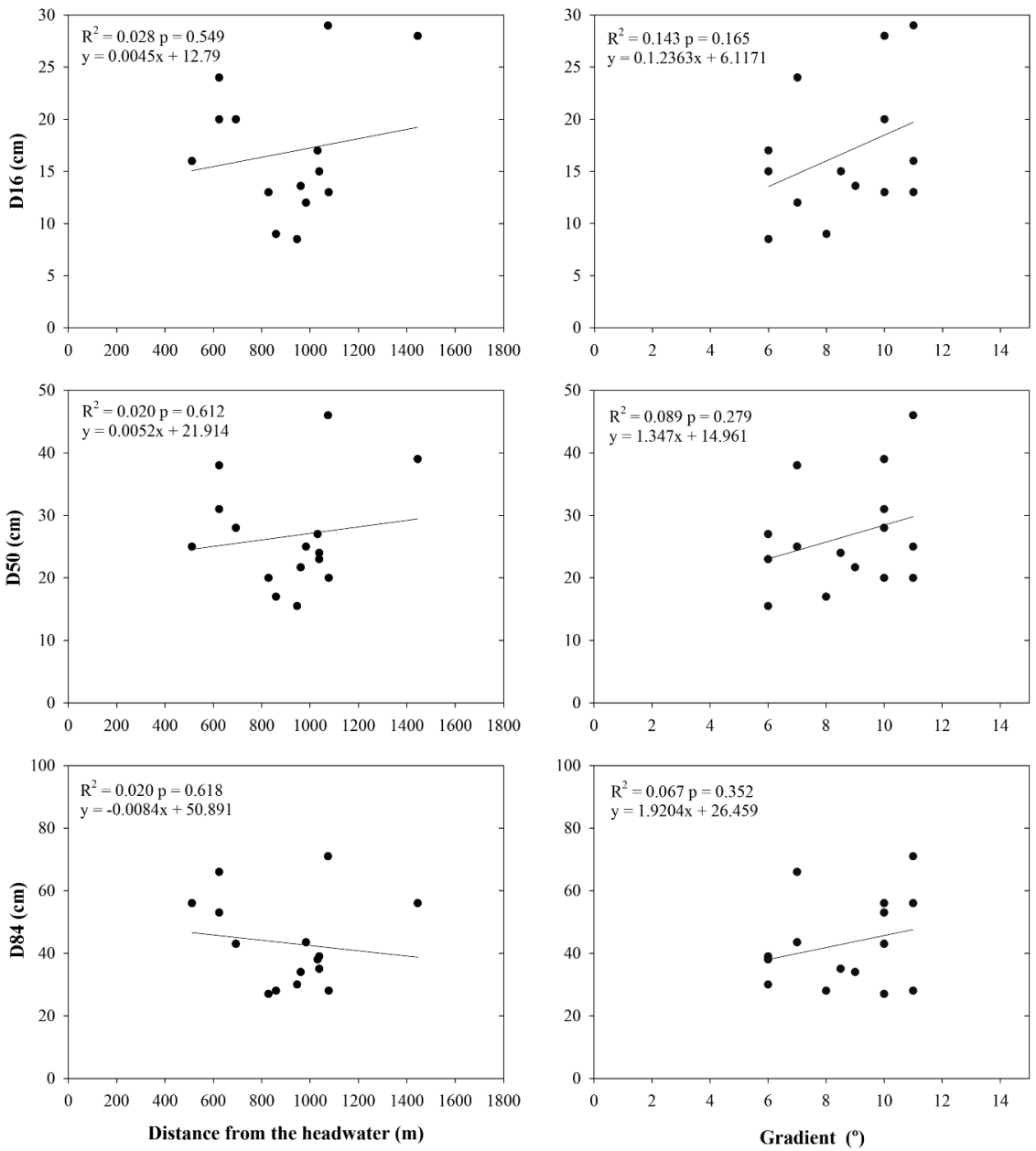

Figure 11. Grain-size distribution as a function of distance and gradient in the old debris flows.

For the channel and the alluvial plain, similar significant results (not shown here) were obtained for the relationships between grain size, distance and gradient in relation to the (a), (b) and (c) axes of the bed materials. For the old debris flows no statistically significant results were found. The most significant results were obtained for the channel, particularly with respect to axis (b).

Regressions were performed for the largest bed materials measured at each sampling point (Fig. 12). The results showed that there was a significant relationship only with distance $\left(\mathrm{r}^{2}=0.211 ; \mathrm{p}=0.048\right)$ and gradient $\left(\mathrm{r}^{2}=0.347 ; \mathrm{p}=0.008\right)$ in the channel, although there was wide dispersion of the points around the regression line for the former, and the $\mathrm{p}$ value was at the limit of significance. 

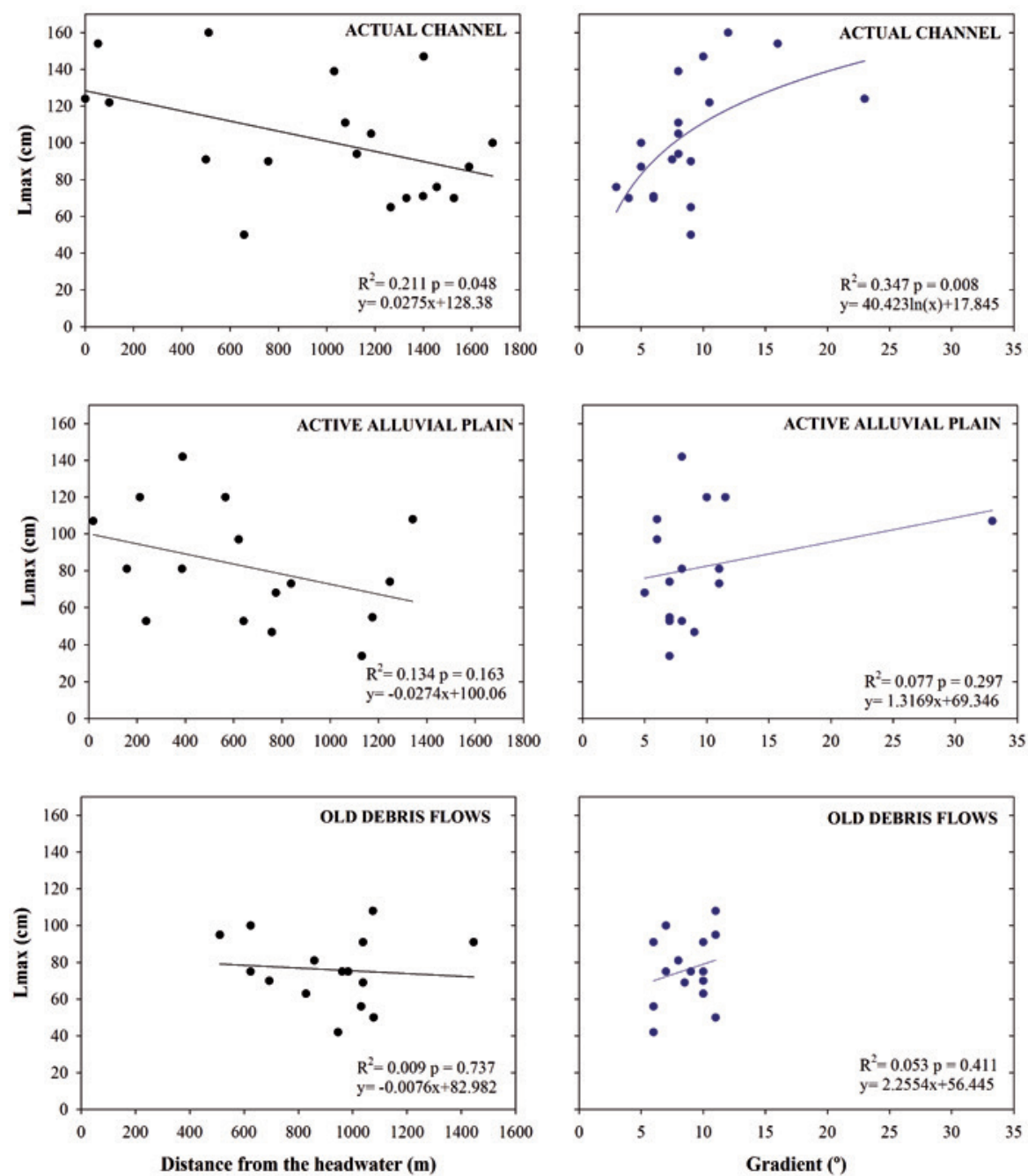

Figure 12. Relationships of the largest bed materials at each sampling point to distance and gradient.

No significant relationships were found for the axis ratios (a)/(b), (a)/(c) and (b)/(c) (data not shown).

The sorting index values were higher for the channel (majority of points approximately 2.5) than for the alluvial plain (approximately 2-2.20). The lowest values (1.47-1.90) were found for the old debris flows. No relationship with distance or gradient was found.

For Hack's (1957) index (Fig. 13) a good relationship was found between the gradient and the $\mathrm{d} 50 /$ drainage area ratio $\left(\mathrm{r}^{2}=0.766 ; \mathrm{p}=0.000\right)$, indicating that the local gradient to a large extent controls the size of boulders, and explains why the size of some boulders is greater than is suggested by the drainage area. 


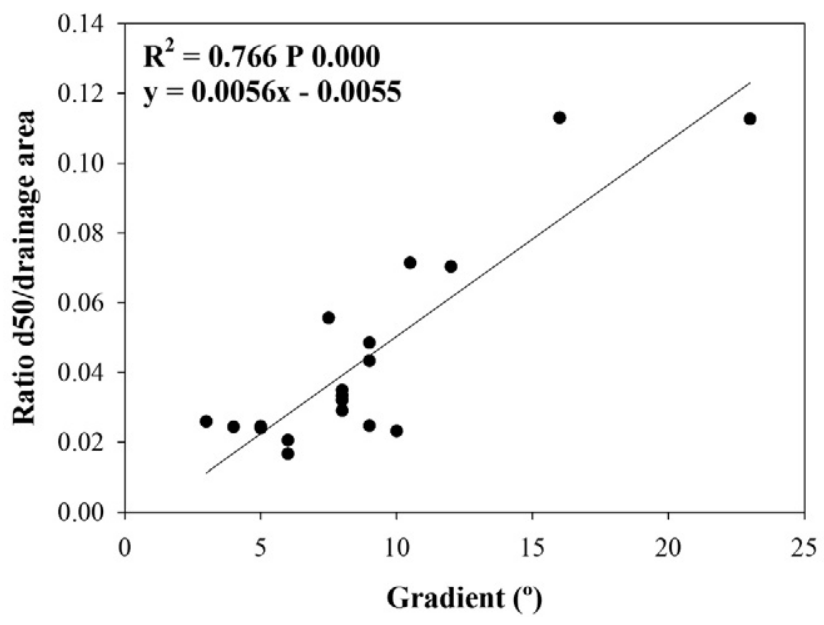

Figure 13. Relationship between gradient and the d50/drainage area ratio in the channel, based on data for the (b) axis.

\section{Discussion}

Rivers in the flysch sector of the central-southern Pyrenees show features of a high torrentiality, braided morphology, and the presence of streambeds dominated by bedload and changing channels and bars. These features are the consequence of flysch characteristics producing high sediment yield from the hillslopes, because of the intensity of faulting and folding and the occurrence of frequent debris flows and landslides near the river banks. This is common to all flysch areas in alpine mountains, as described by Blijenberg (1998) for the Alps. The high sediment yield from the slopes is also related to historical human activity, including deforestation, frequent man-induced fires, overgrazing and cultivation on steep slopes (García-Ruiz and Valero, 1998), including shifting agriculture (Lasanta et al., 2006). South-facing slopes are particularly prone to the occurrence of debris-flows, despite afforestation by public institutions (Ortigosa et al., 1990; Lorente et al., 2002) because they were intensively managed and the soils have been highly disturbed. In the Ijuez Valley, the high population density resulted in cultivation of most of the hillslopes above $1600 \mathrm{~m}$, and a reduction in the upper forest level to enlarge the area for summer pastures. This process resulted in the occurrence of shallow landslides, sheet wash erosion and gullying. The high sediment yield and rapid connectivity between the hillslopes and the channel are the main explanations for the development of a highly torrential streambed along the length of the Ijuez River (Martínez-Castroviejo and García-Ruiz, 1990). Studies on the triggering of debris flows have demonstrated that deforestation lowers the rainfall threshold necessary to initiate debris flows, such that an ordinary rainstorm can cause severe erosion and sediment transport (García-Ruiz et al., 2013). For instance, Lorente et al. (2003) reported that debris 
flows in the flysch sector of the Pyrenees occur with precipitation recurrence intervals of 2-5 years, even though natural and artificial forests have recolonized most of the landscape.

Farmland abandonment, reforestation and afforestation since the middle of the 20th century have contributed to changes in the geomorphic activity, resulting in a decline in the occurrence of debris flows (Beguería, 2006) and consequently their contribution to sediment yield in the basin. Such contribution was estimated in only $13 \%$ of the total (Bathurst et al., 2007). In addition, up to 5 check dams have been constructed in the Ijuez River, causing a reduction in channel activity, narrowing and incision, and colonization of the alluvial plain by willows because of the rapid reduction in sediment connectivity (Quiñonero-Rubio et al., 2013). In the present study we investigated evolutionary and morphological characteristics of the Ijuez River, from the headwater to the first check dam, along an undisturbed reach of approximately 2 $\mathrm{km}$. The first stretch of this reach has an extremely high gradient $\left(19^{\circ}\right)$, including a waterfall and a narrow incised canyon. In the second stretch the valley progressively widens, the gradient is $6-9^{\circ}$, and the following characteristics were evident:

(i) High spatial variability in sedimentary structures and grain size, which is a common feature of most braided rivers (Mosley and Tindale, 1985; Seal and Paola, 1995; Bridge and Lunt, 2006). Thus, during sampling it was important to distinguish the active channel and the active alluvial plain, the latter of which was reorganized and flooded several times each year. Old debris flows deposited above the terrace level were also sampled to enable comparison with the fluvial sediments. Liébault et al. (1999) noted that a high level of spatial variability is typical of small mountain streams, because of coarse sediment inputs from hillslopes, bank erosion and the presence of large organic debris in the channels. Large woody debris can retain sediment for years or decades (Bovis et al., 1998), and become transitory sediment sinks (Nakamura and Swanson, 1993; Gomi et al., 2001). During floods these structures can deliver large volumes of sediment, reinforcing the episodic nature of sediment transport in mountain rivers (Church, 2010).

(ii) The production of large volumes of sediment from a series of incised ravines in the headwater, yielding valley-confined debris flows. The study reach is also affected by lateral erosion, which directly undermines the flysch or degrades the 3-4 m fluvial terrace, resulting in large temporal variability of bedload transport (Bogen, 1995; Lenzi et al., 1999; Alvera and García-Ruiz, 2000). The dependence of bedload transport on the occurrence of debris flows increases uncertainty in relation to bedload, because debris flows are supply-limited systems (Procter et al., 2011) that are not necessarily related to precipitation. This is a characteristic common to braided rivers, and their temporal variability makes it impossible to use equations to predict bedload (MartínVide et al., 1999; Recking et al., 2012) because of the absence of a clear relationship between the occurrence of a rainstorm and the corresponding sediment yield.

(iii) The presence of very steep slopes among the headwater hillslopes and the channel, which produce a high energy environment. This explains the large size of many of the bed materials in both the channel and the alluvial plain, with d50 exceeding $20 \mathrm{~cm}$ in most cases, and d84 exceeding $40 \mathrm{~cm}$. Boulders $>100 \mathrm{~cm}$ were not unconmmon. 
(iv) The formation of a steep sedimentary ramp, having a rectilinear, non-concave longitudinal profile. This ramp occurs over a distance of at least $2 \mathrm{~km}$; it enables the transfer of coarse sediment towards the middle stretch of the river, and causes chaotic spatial organization of sediment within the study reach. The rectilinear longitudinal profile is an indicator of the arrival of large quantities of coarse sediment from the tributaries (Rice and Church, 2001), and contrasts with the usual trend of rivers to develop concave-upward longitudinal profiles (Gasparini et al., 2004). It is clear that some boulders travel greater distances than expected, based on the gradient and distance.

The spatial organization of sediment showed relatively good relationships with grain size and distance, resulting in a general trend to downstream fining (mainly for d50 and d84; Gomez et al., 2001), although the sampling points appear to be highly scattered around the regression line. The rate of fining should follow an exponential model, but this is not the case for the upper Ijuez River fluvial reach, where the downstream fining showed a constant linear trend, probably because of the straight ramp in the longitudinal profile and the high volume of coarse sediment supply (Hoey and Bluck, 1999). The occurrence of heterometric debris flows (which probably evolve into hyperconcentrated flows), the movement of bed material in discrete 'waves' (Church and Kellerhals, 1978), and the random triggering of landslides near the banks result in large variability in the grain size distribution, and account for the presence of large blocks and boulders at any point in the study reach. Thus, the largest boulders at the sampling points showed little relationship to distance or gradient in the active channel, and no relationship in the active alluvial plain, suggesting that these materials travel during floods in massive sediment waves, and their distribution depends on the energy (mass and velocity) of the debris flows within which they travel. This is usual in headwater stretches, where coupling between hillslopes and the channel is so close as to preclude fining trends (Rice, 1999). The absence of a clear concave or exponential longitudinal profile also contributes to this chaotic grain size organization. The relationship between grain size and distance was greater for the channel than for the active alluvial plain, because the latter is mainly composed of reorganized debris flows that are occasionally disturbed during large floods. Statistically significant relationships between grain size and gradient have also been reported. Nevertheless, the use of residuals from the relationships between grain size and distance produced frustrating results when they were considered in relation to gradient, suggesting that gradient is a local characteristic that can be conditioned by the presence of trunks, large boulders and knickpoints throughout the study reach. It is noteworthy that the old debris flows deposited over the terrace level did not show any spatial organization of the bed materials, indicating a massive transport system.

With respect to the relative importance of sorting and abrasion to downstream fining, the results suggest that sorting is the main mechanism explaining the progressive grain size decrease along the study reach. The torrentiality of the Ijuez River and the occurrence of debris and hyperconcentrated flows may result in the boulders being broken into smaller particles, although this process would have had effects on the relationships between the various axes of the bed materials. However, no trend in this relationship was found, and 
consequently sorting appears to be the main factor in downstream fining, as reported previously (Hoey and Ferguson, 1997; Hoey and Bluck, 1999; Surian, 2002). Gomez et al. (2001) demonstrated that maintenance of the gravel form with distance is a sign of sorting rather than abrasion. The occurrence of higher sorting indices in the active channel suggests that water flow introduces greater diversity in the grain size distribution, including large boulders derived from debris flows together with gravels typical of fluvial transport. Grain size diversity was less in the reorganized debris flows of the active alluvial plain, where cobbles and boulders predominated. The sorting index values were lowest in the old debris flows, where only cobbles and boulders were evident in the surface, whereas the sieving effect of the debris flow movement buried the gravels in the inner part of the deposit. Nevertheless, the problem is far from being solved.

\section{Conclusions}

The upper reach of the Ijuez River is torrential, and has a braided-like pattern characterized by the presence of huge accumulations of boulders and cobbles. A detailed field reconnaissance of sedimentary bodies and analysis of the grain size distribution suggested the following conclusions:

(i) The longitudinal profile shows a very steep gradient in the first stretch of the river, where te river runs through a rocky canyon. The gradient declines to 7-9\% over a distance of $2 \mathrm{~km}$, and develops a rectilinear ramp.

(ii) Most of the sediment accumulated in this stretch is produced by valleyconfined debris flows that developed in the subalpine and montane belts, and by landslides in the river banks.

(iii) Four types of sedimentary environments were identified: the channel, the active alluvial plain, the fluvial terrace and old debris flows deposited over the fluvial terrace. This study focused mainly on the former two environments.

(iv) The spatial organization of sediment in the torrential reach showed a progressive decline in the grain size, particularly in the channel. Nevertheless, the spatial variability was large, suggesting reorganized debris flows or hyperconcentrated flows. The distribution of the largest boulders did not show any spatial organization.

(v) The absence of a clear concave or exponential longitudinal profile contributed to the apparently chaotic grain size organization.

\section{Acknowledgements}

Support for this research was provided by the projects INDICA (CGL2011-27753C02-01 and -02) and HIDROCAES (CGL2011-27574-C02-C01) funded by the Spanish Ministry of Economy and Competitiveness, and an agreement between the CSIC and the Spanish Ministry of Environment (RESEL). The Geomorphology and Global Change research group was financed by the Aragón Government and the 
European Social Fund (ESF-FSE). Estela Nadal-Romero was the recipient of a research contract from the Spanish Ministry of Economy and Competitiveness (Juan de la Cierva Programme).

\section{References}

Alvera, B., García-Ruiz, J.M. 2000. Variability of sediment yield from a high mountain catchment, Central Spanish Pyrenees. Arctic, Antarctic and Alpine Research 32, 127-144.

Andrews, E.D. 1983. Entrainment of gravel from naturally sorted riverbed material. Geological Society of America Bulletin 94, 1225-1231.

Bathurst, J.C., Moretti, G., El-Hames, A., Beguería, S., García-Ruiz, J.M. 2007. Modelling the impact of forest loss on shallow landslide sediment yield, Ijuez catchment, Spanish Pyrenees. Hydrology and Earth System Sciences 11 (1), 569-583.

Beguería, S. 2006. Changes in land cover and shallow landslide activity: A case study in the Spanish Pyrenees. Geomorphology 74, 196-206.

Beguería, S., López-Moreno, J.I., Gómez-Villar, A., Rubio, V., Lana-Renault, N., García-Ruiz, J.M. 2006. Fluvial adjustments to soil erosion and plant cover changes in the central Spanish Pyrenees. Geografiska Annaler 88A (3), 177-186.

Benda, L., Hassan, M.A., Church, M., May, C.L. 2005. Geomorphology of steepland headwaters: The transition from hillslopes to channels. Journal of the American Water Resources Association 41 (4), 835-851.

Blijenberg, H. 1998. Rolling stones? Triggering and frequency of hillslope debris flows in the Bachelard Valley, southern French Alps. Utrecht University, Utrecht.

Bogen, J. 1995. Sediment transport and deposition in mountain rivers. In Sediment and water quality in river catchments, I.D.L. Foster, A.M. Gurnell, B.W. Webb (eds.), J. Wiley, Chichester, pp. 437-451.

Boix-Fayos, C., Barberá, G.G., López-Bermúdez, F., Castillo, V.M. 2007. Effects of check dams, reforestation and land-use changes on river channel morphology: case study of the Rogativa catchment (Murcia, Spain). Geomorphology 91, 103-123.

Bovis, M.J., Millard, T.H., Oden, M.E. 1998. Gully processes in coastal British Columbia: the role of woody debris. In Carnation Creek and Queen Charlotte Islands Fish/Forestry Workshop, D.L. Hogan, P.J. Tschaplinski, S. Chatwin (eds.), Land Management Handbook 41, pp. 49-75.

Bridge, J.S., Lunt, A.A. 2006. Depositional models of braided rivers. In Braided rivers. Process, deposits, ecology and management, G.H. Sambrook Smith, J.L. Best, C.S. Bristow, G.E. Petts (eds.), International Association of Sedimentologists, Blackwell Publishing, Special Publication no 36, pp. 11-50.

Brierley, G.J., Hickin, E.J. 1985. The downstream gradation of particle sizes in the Squamish River, British Columbia. Earth Surface Processes and Landforms 10, 597-606.

Brooks, A.P., Brierley, G.J. 1997. Geomorphic responses of lower Bega River to catchment disturbance, 1851-1926. Geomorphology 18, 291-304.

Church, M. 2010. Mountains and montane channels. In Sediment cascades. An integrated approach, T. Burt, R. Allison (eds.), Wiley-Blackwell, Chichester, pp. 17-53.

Church, M., Kellerhals, R. 1978. On the statistics of grain size variation along a gravel river. Canadian Journal of Earth Sciences 15, 1151-1160.

D'Agostino, V. 2013. Assessment of past torrential events through historical sources. In Dating torrential processes on fans and cones. Methods and their application for hazard and risk assessment, M. Schneuwly-Bollschweiler, M. Stoffel, F. Rudolf-Miklau (eds.), Springer, Rotterdam, pp. 131-146. 
Dawson, M. 1988. Sediment size variation in a braided reach of the Sunwapta River, Alberta, Canada. Earth Surface Processes and Landforms 13, 599-618.

Elfström, A. 1987. Large boulder deposits and catastrophic floods. A case study of the Baldakatj area, Swedish Lapland. Geografiska Annaler 69A (1), 101-121.

Ferguson, R., Hoey, T., Wathen, S., Werrity, A. 1996. Field evidence for rapid downstream fining of river gravels through selective transport. Geology 24 (2), 179-182.

Frings, R.M. 2008. Downstream fining in large sand-bed rivers. Earth-Science Reviews 87, 3960.

García-Ruiz, J.M., Puigdefábregas, J. 1982. Formas de erosión en el flysch eoceno surpirenaico. Cuadernos de Investigación Geográfica 8, 85-130.

García-Ruiz, J.M., Puigdefábregas, J. 1985. Efectos de la construcción de pequeñas presas en cauces anastomosados del Pirineo Central. Cuadernos de Investigación Geográfica 11, 91102.

García-Ruiz, J.M., Valero, B. 1998. Historical geomorphic processes and human activities in the Central Spanish Pyrenees. Mountain Research and Development 18 (4), 309-320.

García-Ruiz, J.M., Lana-Renault, N. 2011. Hydrological and erosive consequences of farmland abandonment in Europe, with special reference to the Mediterranean region - A review. Agriculture, Ecosystems and Environment 140, 317-338.

García-Ruiz, J.M., Alvera, B., Del Barrio, G., Puigdefábregas, J. 1990. Geomorphic processes above the timberline in the Spanish Pyrenees. Mountain Research and Development 10 (3), 201-214.

García-Ruiz, J.M., Alatorre, L.C., Gómez-Villar, A., Beguería, S. 2010. Upstream and downstream effects of check dams in braided rivers, Central Pyrenees. In Check dams, morphological adjustments and erosion control in torrential streams, C. Conesa García, M.A. Lenzi (eds.), Nova Science Publishers, New York, pp. 307-322.

García-Ruiz, J.M., Beguería, S., Alatorre, L.C., Puigdefábregas, J. 2010. Land cover changes and shallow landsliding in the Flysch Sector of the Spanish Pyrenees. Geomorphology 124, 250-259.

García-Ruiz, J.M., Arnáez, J., Gómez-Villar, A., Ortigosa, L., Lana-Renault, N. 2013. Firerelated debris flows in the Iberian Range, Spain. Geomorphology 196, 221-230.

Gasparini, N.M., Tucker, G.E., Bras, R.L. 2004. Network-scale dynamics of grain-size sorting: implications for downstream fining, stream-profile concavity, and drainage basin morphology. Earth Surface Processes and Landforms 29, 401-421.

Gómez, B. 1987. Bedload. In Glacio-fluvial sediment transfer. An alpine perspective, A.M. Gurnell, M.J. Clark (eds.), Wiley, Chichester, pp. 355-376.

Gomez, B., Rosser, B.J., Peacock, D.H., Hicks, D.M., Palmer, J.A. 2001. Downstream fining in a rapidly aggrading gravel bed river. Water Resources Research 37 (6), 1813-1823.

Gómez-Villar, A., García-Ruiz, J.M. 2000. Surface sediment characteristics and present dynamics in alluvial fans of the Central Spanish Pyrenees. Geomorphology 34 (2), 127-144.

Gomi, T., Sidle, R.C., Bryant, M.D. 2001. The characteristics of woody debris and sediment distribution in headwater streams, southeastern Alaska. Canadian Journal of Forest Research 31, 1386-1399.

Hack, J.T. 1957. Studies of longitudinal stream profiles in Virginia and Maryland. U.S. Geological Survey Professional Paper 294-B, 45-97.

Hoey, T.B., Ferguson, R.I. 1997. Controls of strength and rate of downstream fining above a river base level. Water Resources Research 33 (11), 2601-2608.

Hoey, T.B., Bluck, B.J. 1999. Identifying the controls over downstream fining of river gravels. Journal of Sedimentary Research 69 (1), 40-50. 
Keesstra, S.D. 2007. Impact of natural reforestation on floodplain sedimentation in the Dragonja basin, SW Slovenia. Earth Surface Processes and Landforms 32, 49-65.

Knighton, A.D. 1980. Longitudinal changes in size and sorting of stream-bed material in four English rivers. Geological Society of America Bulletin 91, 55-62.

Kondolf, G.M., Piégay, H., Landon, N. 2002. Channel response to increased and decreased bedload supply from land use change: contrasts between two catchments. Geomorphology 45, 35-51.

Lana-Renault, N., Alvera, B., García-Ruiz, J.M. 2010. The snowmelt period in a Mediterranean high mountain catchment: runoff and sediment transport. Cuadernos de Investigación Geográfica 36 (2), 99-108.

Lasanta-Martínez, T., Vicente-Serrano, S.M., Cuadrat-Prats, J.M. 2005. Mountain Mediterranean landscape evolution caused by the abandonment of traditional primary activities: a study of the Spanish Central Pyrenees. Applied Geography 25 (1), 47-65.

Lasanta, T., Beguería, S., García-Ruiz, J.M. 2006. Geomorphic and hydrological effects of traditional shifting agriculture in a Mediterranean mountain area, Central Spanish Pyrenees. Mountain Research and Development 26 (2), 146-152.

Leopold, L.B. 1994. A view of the river. Harvard University Press, Cambridge, MA, 298 pp.

Lenzi, M.A., D'Agostino, V., Billi, P. 1999. Bedload transport in the instrumented catchment of the Rio Cordón. Part I: Analysis of bedload records, conditions and thresholds of bedload entrainment. Catena 36 (3), 171-190.

Liébault, F., Clément, P., Piégay, H., Landon, N. 1999. Assessment of bedload delivery from tributaries: the Drôme River case, France. Arctic, Antarctic, and Alpine Research 31 (1), 108-117.

Liébault, F., Gomez, B., Page, M., Marden, M., Peacock, D., Richard, D. Trotter, C.M. 2005. Land-use change, sediment production and channel response in upland regions. River Research and Applications 21, 739-756.

Lorente, A., García-Ruiz, J.M., Beguería, S., Arnáez, J. 2002. Factors explaining the spatial distribution of hillslope debris flows. A case study in the Flysch Sector of the Central Spanish Pyrenees. Mountain Research and Development 22 (1), 32-39.

Lorente, A., Beguería, S., Bathurst, J.C., García-Ruiz, J.M. 2003. Debris flow characteristics and relationships in the Central Spanish Pyrenees. Natural Hazards and Earth System Sciences 3, 683-692.

Marston, R.A., Bravard, J.P., Green, T. 2003. Impacts of reforestation and gravel mining on the Malnant River, Haute Savoie, French Alps. Geomorphology 55, 65-74.

Martí, C., Valero, B., García-Ruiz, J.M. 1997. Large, historical debris flows in the Central Spanish Pyrenees. Physics and Chemistry of the Earth 22 (3-4), 381-385.

Martín-Vide, J.P., Niñerola, D., Bateman, A., Navarro, A., Velasco, E. 1999. Runoff and sediment transport in a torrential ephemeral stream of the Mediterranean coast. Journal of Hydrology $225,118-129$.

Martínez-Castroviejo, R., García-Ruiz, J.M. 1990. Coladas de piedras (debris flows) y dinámica fluvial en ríos torrenciales del Pirineo Central: el caso del río Ijuez. Cuadernos de Investigación Geográfica 16, 55-72.

Montgomery, D.R., Buffington, J.M. 1997. Channel-reach morphology in mountain drainage basins. Geological Society of America Bulletin 109 (5), 596-611.

Mosley, M.P., Tindale, D.S. 1985. Sediment variability and bed material sampling in gravel-bed rivers. Earth Surface Processes and Landforms 10, 465-482.

Moussavi-Harami, R., Mahboudi, A., Khanehbad, M. 2004. Analysis of controls on downstream fining along three gravel-bed rivers in the Band-e-Golestan drainage basin NE Iran. Geomorphology 61, 143-153. 
Nakumura, F., Swanson, F.J. 1993. Effects of coarse debris on morphology and sediment storage in mountain stream systems in western Oregon. Earth Surface Processes and Landforms $18,43-61$.

Picco, L., Ravazzolo, D., Rainato, R., Lenzi, M.A. 2014. Characteristics of fluvial islandas along three gravel-bed rivers of north-eastern Italy. Cuadernos de Investigación Geográfica 40 (1), 53-66.

Ortigosa, L., García-Ruiz, J.M., Gil, E. 1990. Land reclamation by reforestation in the Central Spanish Pyrenees. Mountain Research and Development 10 (3), 281-288.

Powell, D.M. 1998. Patterns and processes of sediment sorting in gravel-bed rivers. Progress in Physical Geography 22 (1), 1-32.

Procter, E., Bollschweiler, M., Stoffel, M., Neumann, M. 2011. A regional reconstruction of debris flow activity in the Northern Calcareous Alps, Austria. Geomorphology 132, 41-50.

Pueyo, Y., Beguería, S. 2007. Modelling the rate of secondary succession after farmland abandonment in a Mediterranean mountain area. Landscape and Urban Planning 83, 245 254.

Quiñonero-Rubio, J.M., Boix-Fayos, C., De Vente, J. 2013. Desarrollo y aplicación de un índice multifactorial de conectividad de sedimentos a escala de cuenca. Cuadernos de Investigación Geográfica 39 (2), 203-223.

Recking, A., Liébault, F., Peteuil, C., Jolimet, T. 2012. Testing bedload transport equations with consideration of time scales. Earth Surface Processes and Landforms 37, 774-789.

Rice, S. 1999. The nature and controls on downstream fining within sedimentary links. Journal of Sedimentary Research 69 (1), 32-39.

Rice, S., Church, M. 1998. Grain size along two gravel-bed rivers: statistical variation, spatial pattern and sedimentary links. Earth Surface Processes and Landforms 23, 345-363.

Rice, S., Church, M. 2001. Longitudinal profiles in simple alluvial systems. Water Resources Research 37 (2), 417-426.

Rickenmann, D. 1997. Sediment transport in Swiss torrents. Earth Surface Processes and Landforms 22, 937-951.

Schumm, S.A. 1977. The fluvial system. Wiley, New York, 338 pp.

Seal, R., Paola, C. 1995. Observations of downstream fining on the North Fork Toutle River near Mount St Helens, Washington. Water Resources Research 31 (5), 1409-1419.

Segura-Beltrán, F., Sanchis-Ibor, C. 2013. Assessment of channel changes in a Mediterranean ephemeral stream since the early twentieth century. The Rambla de Cervera, eastern Spain. Geomorphology 201, 199-214.

Surian, N. 2002. Downstream variation in grain size along an Alpine river: analysis of controls and processes. Geomorphology 43, 137-149.

Trimble, S.W. 1999. Decreased rates of alluvial sediment storage in the Coon Creek basin, Wisconsin, 1975-93. Science 285, 1244-1246.

Vicente-Serrano, S.M., Lasanta, T., Romo, A. 2004. Analysis of spatial and temporal evolution of vegetation cover in the Spanish Pyrenees: role of human management. Environmental management 34 (6), 802-818.

White, S., García-Ruiz, J.M., Martí, C., Valero, B., Errea, M.P., Gómez-Villar, A. 1997. The 1996 Biescas campsite disaster in the Central Spanish Pyrenees and its temporal and spatial context. Hydrological Processes 11, 1797-1812.

Wolman, M.G. 1954. A method of sampling coarse river-bed material. Transactions of the American Geophysical Union 35, 951-956. 